\title{
National policy space: reframing the political economy of globalization and its implications for national sovereignty and democracy
}

\author{
Espaço de politica nacional: reformulando \\ a economia política da globalização e suas implicações \\ para a soberania nacional e a democracia
}

THOMAS PALLEY*

RESUMO: Este artigo critica o enquadramento do trilema da economia política da globalização e oferece um enquadramento alternativo baseado na construção do espaço da política nacional. $\mathrm{O}$ artigo faz três contribuições principais. Em primeiro lugar, partindo de Stein (2016), desconstrói as categorias utilizadas por Rodrik (2011) e introduz distinções entre o "grau", "tipo" e "dimensões" da globalização; Soberania nacional "efetiva" versus "formal”; "Conteúdo" versus "processo" da democracia; e democracia "nacional” versus "global". A desconstrução mostra que os países enfrentam escolhas envolvendo uma série de margens, não um trilema. Em segundo lugar, isso sugere reformular a problemática em termos de espaço de política nacional, que é o "funil” por meio do qual a globalização impacta a democracia e a soberania nacional. Terceiro, o documento mostra que um país pode ser impactado pela globalização mesmo que não faça nada porque as ações de outros países mudam seu conjunto de possibilidades. O reenquadramento mostra que a globalização é um projeto intrinsecamente político. Na medida em que agora está gerando uma virada nacionalista e antidemocrática na política, a responsabilidade recai sobre as elites políticas. PALAVRAS-CHAVE: Globalização; trilema; espaço de política; soberania; democracia; política de bloqueio.

ABSTRACT: This paper critiques the trilemma framing of the political economy of globalization, and offers an alternative framing based on the construction of national policy space. The paper makes three main contributions. First, building on Stein (2016), it deconstructs the categories used by Rodrik (2011) and introduces distinctions between the "degree", "type", and "dimensions" of globalization; "effective" versus "formal" national sovereignty; "content" versus "process" of democracy; and "national" versus "global" democracy. The deconstruction shows countries face choices involving a series of margins, not a trilemma. Second, that suggests reframing the problematic in terms of national policy space, which is

\footnotetext{
* Independent researcher. Economist, Washington/DC, United States. E-mail: mail@thomaspalley.com. Orcid: https://orcid.org/0000-0002-0319-3157. Submitted: 5/January/2021; Approved: 7/January/2021.
} 
the "funnel" through which globalization impacts democracy and national sovereignty. Third, the paper shows a country can be impacted by globalization even if it does nothing because other countries' actions change its possibility set. The reframing shows globalization is an intrinsically political project. To the extent it is now driving a nationalistic anti-democratic turn in politics, responsibility lies with political elites.

KEYWORDS: Globalization; trilemma; policy space; sovereignty; democracy; policy lock-in. JEL Classification: F0; F02; F50.

\section{INTRODUCTION: TRILEMMA VERSUS NATIONAL POLICY SPACE AND WHY IT MATTERS}

In his best seller, The Globalization Paradox: Democracy and the Future of the World Economy, Dani Rodrik (2011) introduced the notion of the globalization political trilemma which has quickly gained widespread currency. According to Rodrik, there is an inescapable conflict among economic globalization, the nation state, and democratic politics. Countries can have any two, but not all three.

This paper critiques the trilemma framing of the political economy of globalization, and offers an alternative framing rooted in the construct of national policy space. Globalization causes changes in national policy space that have drop-down implications for national sovereignty and democratic politics. Globalization involves choices regarding the "degree", the "type", and the "dimensions" of international economic integration. Contrary to the trilemma, the multi-faceted nature of the choices means there are no inevitable implications for sovereignty or democracy.

The trilemma framing has done a major service by redirecting attention to the political governance implications of globalization. Those impacts and their consequences are insufficiently attended to, especially by economists who focus on the immediate narrowly defined economic impacts. That said, the paper presents a critique of the trilemma, which is in part technical critique, and in part political critique. The technical critique concerns the trilemma's framing of the mechanics and impacts of globalization. The political critique is that the trilemma's framing of the mechanics risks misdirecting the policy conversation and obscuring political responsibility for anti-democratic developments.

The paper is related to an important paper by Stein (2016) which is concerned with many of same issues that motivate the current paper. Stein frames the discussion in terms of frictions among democracy, sovereignty, and globalization. However, at the end of the day, he persists with the usefulness of the trilemma framing. In contrast, the current paper argues the problematic of globalization is better channeled (theoretically and politically) through the frame of national policy space.

The structure of the paper is as follows. The second and third sections critically assess the globalization political trilemma, while fourth-seventh sections provide an alternative model based on the construct of national policy space. The second section revisits the trilemma hypothesis. Third section deconstructs the trilemma and surfaces various analytical concerns. Fourth section presents an encompassing model for understanding globalization, which is then expanded in the rest of the paper. Fifth 
section expands the analysis to represent globalization as a politically sponsored twisting of national policy space. The sixth section further expands the analysis to incorporate policy lock-in. Seventh section discusses some of the implications of the proposed framework for nation state democratic politics. Eight section concludes.

\section{THE GLOBALIZATION POLITICAL TRILEMMA HYPOTHESIS REVISITED}

Rodrik's "globalization trilemma" hypothesis pivots linguistically off the "macroeconomic policy trilemma" coined by Obstfeld and Taylor (1997), which has been relabeled the "impossible trinity" by Krugman (1999). The impossible trinity is an argument about international economic arrangements. ${ }^{1}$ The globalization trilemma is an analogue argument about international political economy, and it rests on the assumption that there exists a fundamental tension among globalization, the nation state, and democracy.

Figure 1 reproduces Rodrik's (2011, p. 201) globalization political trilemma. There are three characteristics to the political economic system: hyper-globalization, the nation state, and democratic politics. The argument is that countries can have any two characteristics but not all three. To illustrate the trade-off, Rodrik identifies three different political regimes: the golden straitjacket regime which corresponds to the 19th century gold standard when there was hyper-globalization with nation states; the Bretton Woods regime of the mid-20th century when democratic nation states imposed limits on globalization via tariffs and quotas, managed exchange rates, and capital mobility controls; and an imagined 21st century regime of hyperglobalization in a world where the nation state has disappeared and been replaced by global democratic governance.

Figure 1: The globalization political trilemma

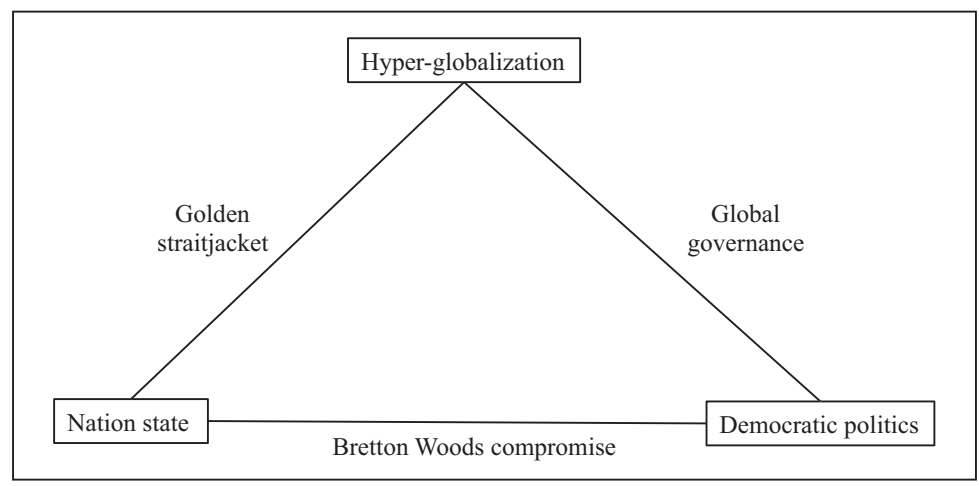

Source: Rodrik (2011, p. 201)

\footnotetext{
${ }^{1}$ The impossible trinity argument concerns the consistency of flexible exchange rates, international financial capital mobility, and monetary policy effectiveness.
} 
The three regimes are distinct, with each having two of the three characteristics. The golden straitjacket regime is claimed to be inconsistent with democratic politics; the Bretton Woods compromise is inconsistent with hyper-globalization; and the global governance regime is inconsistent with the nation state.

\section{CRITIQUE OF THE GLOBALIZATION POLITICAL TRILEMMA}

This section presents a two-part critique of the globalization trilemma. Figure 2 begins the critique by re-labelling the trilemma diagram. "Hyper-globalization" is re-labelled as "Deep international economic integration"; the "Golden straitjacket" is re-labelled as "Deep integration via laissez-faire"; "Global governance" is re-labelled as "Deep integration via global rule-making"; and the "Bretton Woods compromise" is re-labelled as "Managed country specific economic integration". Lastly, the "nation state" is replaced by "national sovereignty". ${ }^{3}$ The re-labelling exercise helps surface the analytical problems within the original construction.

Figure 2: The globalization political trilemma relabelled

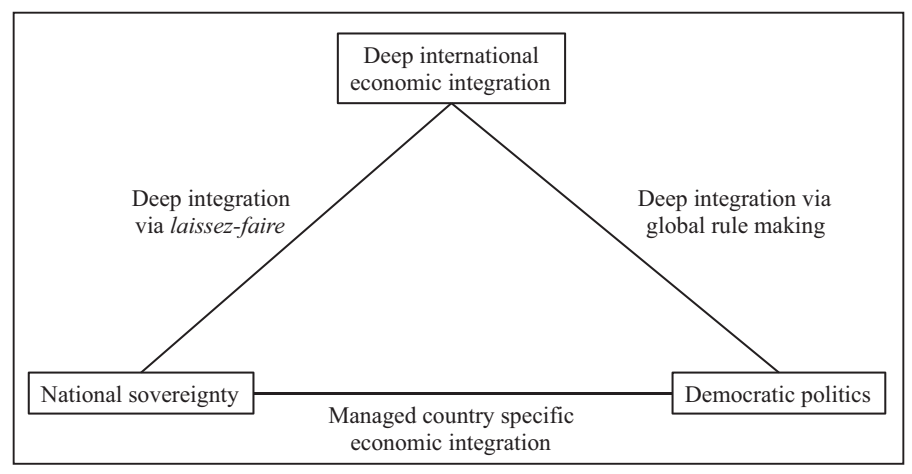

Source: Prepared by the author.

\section{a) Claims about globalization's impact on national sovereignty and democratic politics}

A first set of problems concerns the base of the triangle and the claims about the impact of different globalization regimes on national sovereignty and democratic politics. National sovereignty refers to the ability to control the rules of governance and influence economic outcomes within a country's borders. According to the trilemma diagram, global integration via laissez-faire leaves national

\footnotetext{
${ }^{2}$ The relabeled trilemma is similar to that implicit in Stein (2016), though he does not actually produce such a diagram.

${ }^{3}$ In the text discussing the trilemma, Rodrik (2011, p. 201) refers to "national self-determination" but, unfortunately, does not use that terminology in his trilemma diagram.
} 
sovereignty intact and unaffected. That claim is suspect. Deep global integration means borders are open to the inflow of goods, services, capital, and people. As long as the rules of the game endure, a country is unable to adjust the terms of entry which are a critical dimension of governance. The 19th century laissez-faire system was also based on the gold standard. That system involved a degree of loss of sovereignty via commitment to a fixed gold exchange parity. Today's financial system also involves losses of sovereignty as countries commit to accounting standards and financial regulations. The bottom line is any form of international agreement tacitly constitutes a loss of sovereignty, and it is ontologically impossible to think of deep international economic integration without such agreements.

On the other side of the triangle's base, the trilemma claims integration by global rule making involves total loss of national sovereignty. That too is suspect. Global rulemaking does involve surrender of exclusive national decision making, but "effective" national sovereignty may be enhanced. Effective sovereignty is defined as a country's ability to shape and control what goes on within its borders.

The international economy is intrinsically relational. As discussed further in the fourth section below, what a country can do depends on what other countries are doing and on the technologies governing production and commerce in the global economy. Given that, effective sovereignty may be enhanced by joining a collective rulemaking group in which a country has a seat at the table. There is need to distinguish between "effective" and "formal" sovereignty. Laissez-faire globalization retains formal national sovereignty but may undermine effective national sovereignty. Collective rulemaking undercuts formal national sovereignty but may enhance effective national sovereignty. ${ }^{4}$

The trilemma's framing of the impact of globalization regimes on democratic politics is equally fraught. Here, it fails to distinguish among national politics, democracy as process, and the content of democratic politics.

Collective global rulemaking supposedly retains democratic politics. However, it suppresses national democratic politics. As part of that, the democratic process is significantly altered since the electorate becomes global, which substantially diminishes the sense of representation felt by national citizens. That is a very different picture from the trilemma's presentation of democratic politics being maintained.

Side-by-side, laissez-faire globalization supposedly eliminates democratic politics. However, there is no reason to believe national democratic politics disappears since the process remains intact (as exemplified by post-Brexit politics in the UK). That said, laissez-faire globalization may diminish the "content" of national democratic politics, with augmented global market competition undermining the viability of some policies and thereby taking them off the table, de facto. That possibility is real, but it also implicitly challenges the trilemma's claim that laissez-faire globalization leaves national sovereignty unaffected.

In sum, deconstructing the globalization political trilemma highlights the need

\footnotetext{
${ }^{4}$ This point is made by Verovšek (2020) in connection with the Brexit debate.
} 
to distinguish between the "process" of democracy and the "content" of democracy, "formal" sovereignty versus "effective" sovereignty, and "national" democracy versus "global" democracy. Recognizing those distinctions dissolves the trilemma's claim that deep integration either leaves either sovereignty unaffected or democratic politics unaffected. Sovereign democratic nation states operate in a context. Globalization inevitably changes that context in ways which inevitably implicate both sovereignty and democracy.

\section{b) Incomplete regime possibility set}

A second set of problems concerns the trilemma's identification of the regime possibility set. The triangle is supposed to identify all the possible economic globalization regimes. The base corresponds to shallow international economic integration, whereas the right-hand side (RHS) and left-hand side (LHS) of the triangle correspond to regimes of deep international economic integration under alternative governance regimes. Figure 3 contains a $2 \times 2$ matrix, defined over governance (nation state vs. global) and type of integration (laissez-faire vs. social democratic), which illustrates the mix of possible regimes. Missing from the trilemma is the possibility that nation states may negotiate a social democratic deep integration regime with high standards. Yet, as discussed in the fifth section below, the type of economic integration has critical implications for national sovereignty and democratic politics. In sum, to understand globalization's political impacts it is necessary to unpack both the governance structure and the type of globalization, which jointly determine the political implications.

Figure 3: Regimes of deep economic integration.

\begin{tabular}{|c|c|c|c|}
\hline & & \multicolumn{2}{|c|}{ Economic integration } \\
\hline & & Laissez-faire & $\begin{array}{c}\text { Social } \\
\text { democratic }\end{array}$ \\
\hline \multirow{2}{*}{ Governance } & $\begin{array}{c}\text { Nation } \\
\text { state }\end{array}$ & LHS & $?$ \\
\hline & Global & & RHS \\
\hline
\end{tabular}

\section{NATIONAL POLICY SPACE: REFRAMING THE POLITICAL ECONOMY OF GLOBALIZATION}

The trilemma identifies three different economic policy regimes and seeks to attach political implications. This section reframes the political economy of globalization in terms of national policy space. In the initial simple model, that renders 
the political economy of globalization as a dilemma rather than trilemma. In the expanded model, it may or may not pose a dilemma.

Figure 4 shows the framework which generates a political cascade. Nation states face a choice regarding the degree of globalization, with the choice ranging from autarky to hyper-globalization. The degree of globalization is determined by the rules of international economic integration. Those rules impact the range of national policy space which, in turn, has dropdown implications for nation state democratic politics.

Figure 4: The globalization dilemma: economic integration, policy space, and democracy (+ = more policy space, - = less policy space)

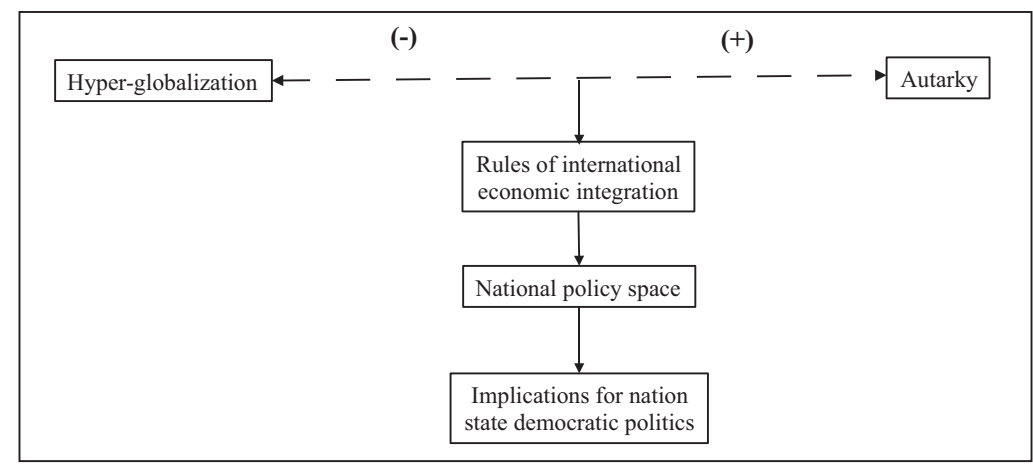

Source: Prepared by the author.

According to Figure 4 national democratic politics are implicated by globalization via the latter's impact on national policy space. As discussed in fourth and fifth sections the impact on policy space depends on the particulars of the way in which global economic integration is designed. Additionally, globalization's impact on policy space operates through direct and indirect channels. As regards direct impacts, it can affect policy content via global governance treaty arrangements that have national governments surrender a degree of sovereignty and intentionally handcuff themselves by agreeing to limits on what they can do (Gill, 1998; Gill and Cutler, 2014). As regards indirect impacts, it can affect the "policy content" of democratic politics by undermining the effectiveness of policy modalities and instruments, thereby de facto restricting policy choices.

For sovereignty and democracy, the question is how do these policy space impacts play out with regard to policy effectiveness and political practice? The impact of treaty agreements on policy possibilities is self-explanatory. However, the impact of reduced policy effectiveness on policy possibilities is tacit. It works via globalization induced changes in economic structure that undermine the feasibility and effectiveness of policy. Thus, policies that were previously effective may become ineffective. Alternatively, they may become too costly to pursue, rendering them de facto ineffective. Examples of this are corporate taxation and regulation which can become less viable owing to the threat of capital mobility. 
There are several important features to notice about Figure 4. First, globalization is a continuum, rather than a binary choice. Furthermore, as argued in the fifth section below, there are also different "types" of globalization and different "dimensions" of globalization which have different policy characteristics that further complicate the argument.

Second, the assumption in Figure 2 is that increased globalization diminishes national policy space, as indicated by the plus and minus signs. That reflects the framing of globalization as a one-dimensional phenomenon, which is also the conventional assumption. However, as argued in the fifth section below, a more refined treatment of globalization shows that is not necessarily so and the policy space impact depends on the type of globalization.

Third, the political impact of globalization on democracy operates indirectly via globalization's impact on national policy space. That indirect impact is critical and introduces the important distinction between the "process" of democratic politics versus the "policy content" and "quality" of democratic politics.

Globalization has no automatic impact on the process of democratic politics, regardless of degree or type of globalization. However, globalization impacts economic outcomes and it can impact the policy content of democratic politics via its impacts on national policy space. How those impacts play out politically is highly contingent and dependent on the responses of national political establishments.

\section{A SIMPLE MODEL: THEORIZING THE RELATION BETWEEN GLOBALIZATION AND NATIONAL POLICY SPACE}

Figure 4 maps the causal chain between globalization and nation state democratic politics. The next step is to excavate and theorize the mechanics of that chain. The impact of globalization on national policy space is central to the argument. The mechanics of that impact is illustrated in Figure 5 which provides a graphical formalization of the relationship between globalization and policy space.

A country's policy space is described by a policy index $(\mathrm{P})$ which captures the amount of policy space it has. Higher values of $\mathrm{P}$ confer greater policy space, which yields a wider feasible range for the policy target $(\mathrm{X})$. The policy index declines as globalization $(G)$ increases, which reduces the feasible range for the policy target variable. In Figure 5 there is a single policy target (which enables two-dimensional graphical representation). In reality, there is a vector of policy targets.

The right-hand panel of Figure 5 shows that policy space decreases as the globalization increases. The relationship is represented as non-linear. Initially, globalization may produce only small losses of policy space: then the losses may steepen as the impacts of deeper globalization begin to bite; and once the system is highly globalized, the policy space losses from further marginal increases in globalization may slow again. The current level of globalization is $G_{0}$. 
Figure 5: Globalization and national policy space

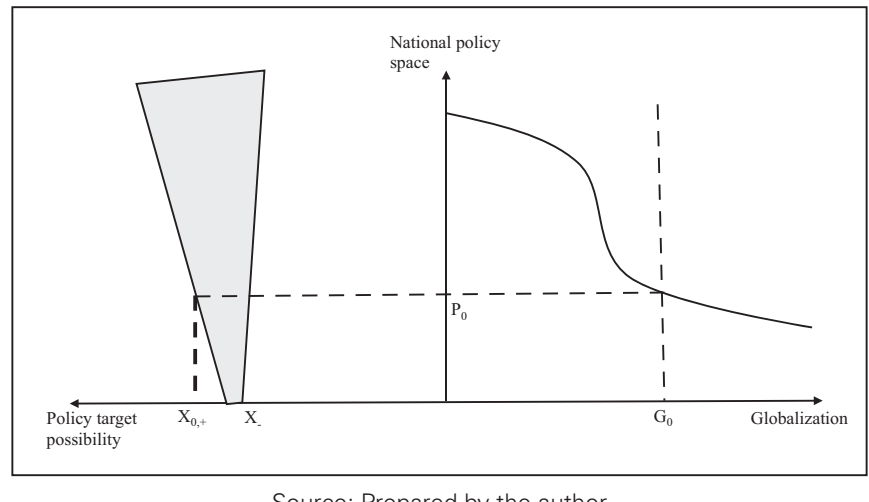

Source: Prepared by the author.

The left-hand panel shows the range of the policy target variable that national policymakers can achieve. As globalization increases and national policy space declines, the achievable range shrinks. For a given level of globalization, $\mathrm{G}_{0}$, the achievable range of the policy target variable $(\mathrm{X})$ that the policymaker can hit is

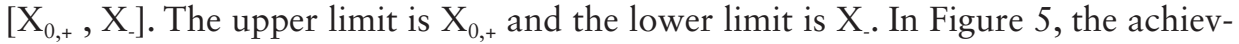
able range shrinks as globalization deepens owing to a decline in the achievable upper limit (i.e., the best outcome).

Figure 5 captures the logic of Keynes' (1933) famous essay titled "National Self-Sufficiency". In that essay, Keynes argued for a retreat from international economic openness, and especially financial capital mobility. The essence of his argument for a greater degree of national self-sufficiency and economic isolation among countries was to allow them policy space to pursue different national ideals:

But let goods be homespun whenever it is reasonably and conveniently possible, and, above all, let finance be primarily national [...] the policy of an increased national self-sufficiency is to be considered, not as an ideal in itself, but as directed to the creation of an environment in which other ideals can be safely and conveniently pursued. (Keynes, 1933).

For Keynes, the issue was not about internationalization (i.e., globalization) being in contradiction with the democratic process. It was about internationalization restricting the policy space in which democratic nations could pursue different social ideals.

From the perspective of the nation state there is no trilemma, only a dilemma. National sovereignty or the nation state can be identified with national policy space. Globalization creates a trade-off between national policy space and the degree of globalization, with national policy space declining as globalization deepens. It is in that specific sense that there is a conflict between globalization and the nation state. Globalization diminishes national sovereignty (i.e., the nation state) by diminishing national policy space. 
In fact, the problem is likely more complex than illustrated in Figure 5 because a country that seeks to avoid globalization may still find its policy space impacted by globalization. This is illustrated in Figure 6 . Let $G^{*}$ denote the degree of globalization in the rest of the world. As globalization increases in the rest of the world $\left(G_{0}^{*}<G_{1}^{*}\right)$, policy space decreases in country i despite unchanged local engagement with globalization $\left(\mathrm{P}_{\mathrm{i}, 0}\left(\mathrm{G}_{\mathrm{i}, 0}, \mathrm{G}_{1}{ }_{1}\right)<\mathrm{P}_{\mathrm{i}, 0}\left(\mathrm{G}_{\mathrm{i}, 0}, \mathrm{G}_{0}^{*}\right)\right)$, which reduces the achievable range of the policy target $\left(\mathrm{X}_{\mathrm{i}, 0+}\left(\mathrm{G}_{\mathrm{i}, 0}, \mathrm{G}_{1}^{*}\right)<\mathrm{X}_{\mathrm{i}, 0_{+}}\left(\mathrm{G}_{\mathrm{i}, 0}, \mathrm{G}_{0}^{*}\right)\right)$.

Figure 6: The effect of increased globalization in the rest of the world $\left(G^{*}{ }_{0}<G^{*}{ }_{1}\right)$ on national policy space in country $i$

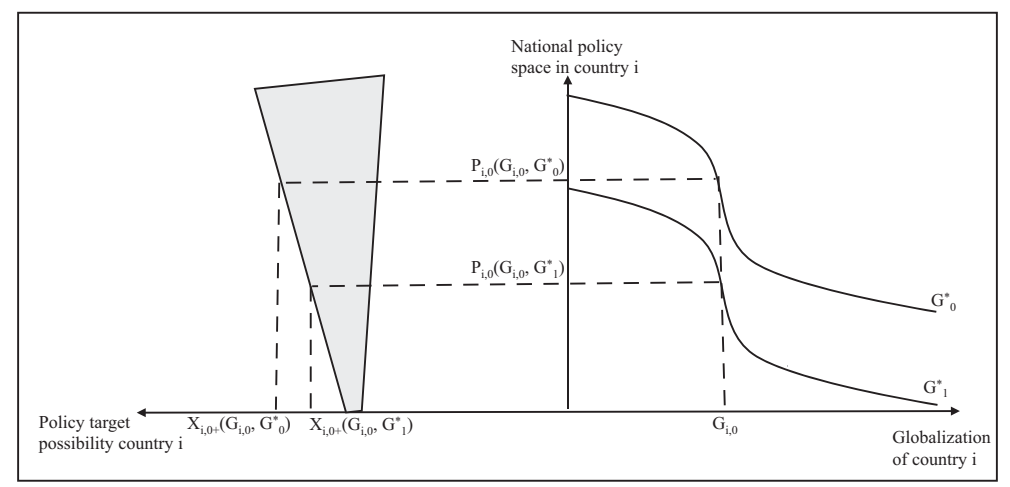

Source: Prepared by the author.

Figure 6 describes a critical under-appreciated aspect of globalization. That aspect is increased globalization by other countries can impose a negative externality in the form of reduced policy space for non-participating countries. That is because the international economy is intrinsically "relational". Consequently, when other countries deepen their globalization, that can impose additional constraints on countries because it may negatively impact the latter's network of relations. The exact nature of the impacts will depend on the type of globalization adopted by the rest of the world.

Figures 5 and 6 constitute a unified analytical framework. Figure 5 shows globalization as a choice, with countries choosing their degree of globalization. Figure 6 shows globalization is also something that happens to countries owing to outside developments. The full picture involves both.

Though not the main focus of the current paper, the above framing of globalization in terms of policy space spotlights an economic cost that is over-looked by economists in their cost-benefit assessment of globalization. Mainstream (i.e., neoclassical) economics views globalization through the lens of mutually beneficial exchange, with globalization offering expanded opportunity for such exchange. That perspective inevitably lends itself to the conclusion that globalization is welfare enhancing, leaving only the "scale" of gains up for debate. A policy space perspective questions that since loss of policy space can impose significant costs. Those costs depend on the character of the economy and the value of policy inter- 
ventions. In a perfectly competitive economy (i.e., the neoliberal assumption) that value is small. However, in a Keynesian economy that value may be large.

As regards democracy, the effects are complex. The first point is that globalization impacts both democratic and non-democratic governments. It does so by impinging "policy space". In the above model, for both regimes there is no trilemma, just a dilemma between the benefits of globalization versus the costs of changed policy space. Second, the democratic process per se is unaffected. Third, globalization may diminish the "content" of democratic politics, as measured by policy space and the achievable range of the policy target. However, the content of democratic politics might be better considered an issue of sovereignty. Fourth, there may be adverse indirect impacts on democracy if diminished policy content causes political frustrations that generate an anti-democratic backlash, as discussed in section seventh below. Those last two points show the inter-connectedness of democracy and sovereignty, which runs counter to the trilemma's construction. If there is a threat to democracy, it runs though "content" and not through "process".

\section{REFINING THE MODEL: GLOBALIZATION AS POLITICALLY DRIVEN TWISTING OF NATIONAL POLICY SPACE}

Both the trilemma and the model in the previous section described globalization as a monolithic single-dimensioned phenomenon, in which case it poses a dilemma between deep global economic integration and national policy space. This section refines the model by introducing a distinction among different "types" of globalization and different "dimensions". That expands the choice set and makes politics even more important. It also means that not every choice is a dilemma.

In many regards, the discussion of globalization has been compromised by the intellectual hegemony of neoliberalism, which has encouraged thinking about globalization exclusively in terms of neoliberalism. Globalization is defined as deep global economic integration. Neoliberal globalization is organized according to neoliberal principles. However, global integration can also be organized along other political economic lines.

That possibility introduces different "types' of globalization and political preferences, which has significant analytic implications. The model in the fourth section emphasized the "degree" of globalization. Now, there is also need to consider the "type" of globalization. Moreover, both degree and type will depend on political preferences, rendering globalization a politically driven twisting of national policy space.

That has significant implications. First, whether or not globalization even poses a dilemma now depends on preferences, as those who win from globalization (i.e., get to implement their preferred globalization) may see no dilemma. Second, the consequences for democracy will also depend on the type of globalization.

In the simple model shown in Figure 5 there was just one type of globalization, and political attitudes toward globalization will depend on political preferences regarding the policy target variable, X. For instance, let X correspond to the wage 
share of national income, with a low value of $\mathrm{X}$ corresponding to a low wage share. Political parties with a preference for a high wage share will then prefer a low level of globalization $(G)$ as that gives them more policy space $(P)$ to potentially achieve a high wage share $(\mathrm{X})$. Conversely, political parties with a preference for a low wage share and high profit share will prefer a high level of globalization, because that imposes restraints on national policy space which lower the maximum wage share that can be achieved. The implication is that once political preferences are introduced the dilemma formulation needs to be qualified. Globalization poses a dilemma for those whose policy possibilities are restricted, but it is a benefit for those whose policy possibilities are enhanced.

The model in Figure 5 illustrates how globalization impacts policy space and the significance of political preferences for understanding political attitudes toward globalization. However, the model suffers from presenting globalization as if there is a single unique form $(\mathrm{G})$. In fact, globalization is not a monolithic outcome. Instead, it is a designed system that works to impose new rules of economic governance.

Fifty years ago, trade agreements were about reducing tariffs and quotas. Today, they are better described as "global governance agreements" (Palley, 2016) that are writing the rules of a new world order. As Renato Ruggerio (1996), the first General Secretary of the World Trade Organization (WTO) observed at its onset: "We are no longer writing the rules of interaction among separate national economies. We are writing the constitution of a single global economy". These global governance agreements fundamentally impact national policy space. A clear example of this is the new system governing disputes between governments and foreign-based corporate investors, which involves an extra-legal investor - state dispute settlement (ISDS) process that is outside of nations' own legal systems.

The impact of globalization depends on its design, reflecting the fact that its design comes in different political flavors. This can be illustrated through the concept of a policy possibility frontier (PPF), as shown in Figures 7.a and 7.b. National policy outcomes are described in terms of left/social democratic outcomes $(\mathrm{L})$ and right/market fundamentalist (R), with the policy possibility frontier (PPF) describing the mix of outcomes that are viable. Globalization can twist the PPF, with the nature of the twist depending on design.

Figure 7.a describes the case of neoliberal or corporate globalization. The initial PPF is described by the solid line. Neoliberal globalization rotates the PPF counterclockwise, diminishing the value of $\mathrm{L}$ that can be achieved. Figure 7.b describes the case of ultra-neoliberal globalization. Again, the initial PPF is described by the solid line. Now, not only does globalization diminish the maximum attainable value of $\mathrm{L}$, it also increases the maximum attainable value of R. Neoliberal globalization poses a dilemma for social democrats, but it is a boon for neoliberals.

An example of the type of policy that twists the PPF as described in Figures 7.a and 7.b is increased financial capital mobility, which enables financial markets to further discipline governments. That diminishes space for delivering left/social democratic outcomes (i.e., diminishes maximum $\mathrm{L}$ ) and increases space for neoliberal outcomes (i.e., increases maximum R). 
Figures 7.a and 7.b.: Neoliberal globalization and the twisting of national policy space

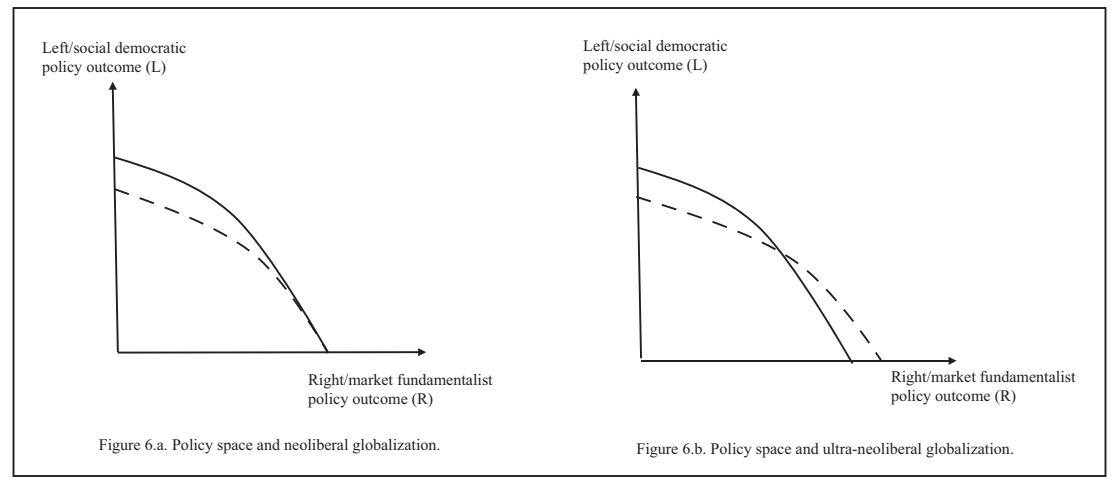

Source: Prepared by the author.

Another example of ultra-neoliberal globalization is implementation of ISDS settlement procedures that allow foreign investors to sue for damages re regulations that diminish the value of their profits. Such procedures effectively deter regulation, thereby diminishing the value of L. Simultaneously, ISDS procedures may be paired with rules strengthening and extending intellectual property rights that increase the maximum attainable value of $R$.

An alternative left/social democratic globalization is shown in Figures 8.a and 8.b. such a globalization would involve such policies as enforceable international labor and environmental standards, standards governing corporate behavior, managed exchange rates, managed capital mobility, and rules on tax transparency and tax competition (see Palley, 2012, p. 170-185 and 2015). Figure 8.a shows the case of social democratic globalization which constrains market fundamentalist policy outcomes. Figure 8.b shows the case of ultra-social democratic globalization which constrains market fundamentalist policy outcomes and expands social democratic possibilities.

Figures 8.a and 8.b: Social democratic globalization and the twisting of national policy space

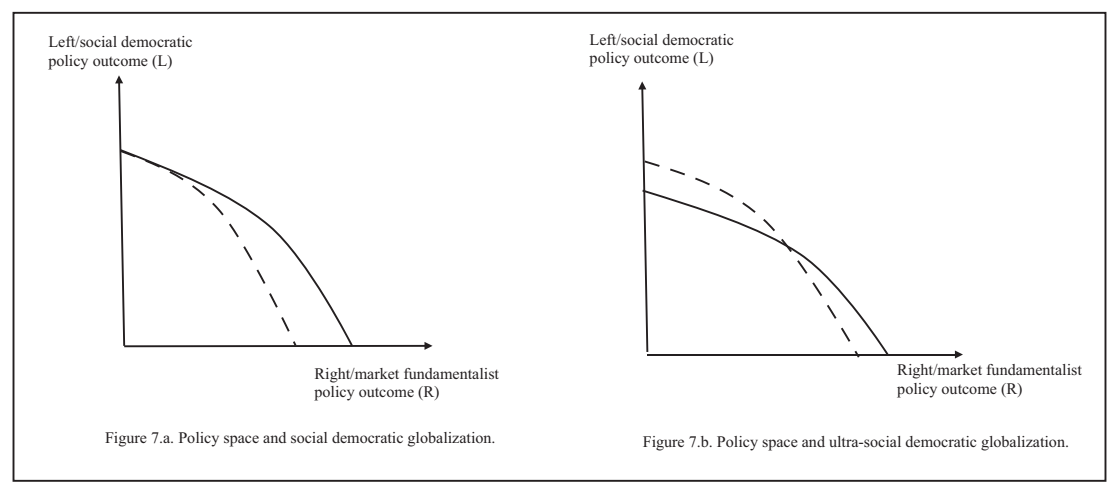

Source: Prepared by the author. 
The above representation of globalization in terms of policy possibility frontiers enriches understanding. First, and most importantly, it shows there is no unique natural globalization. Instead, globalization varies with design so that there are different types, and designs have different political complexions.

Second, globalization does more than "shrink" national policy space. It also "twists" national policy space. Thus, it may shrink policy space along some dimensions and expand it along others. The complaint with the current ultra-neoliberal globalization is that it has twisted national policy space in favor of right/market fundamentalist possibilities by diminishing social democratic possibilities and expanding market fundamentalist possibilities.

Taken together, the implication is globalization operates over multiple "dimensions"; within each dimension there are differences of "degree"; and for each dimension there are different "types" (i.e., designs). For instance, neoliberal globalization can be considered a mix of laissez-faire and global rule-making globalization. There is laissez-faire with regard to movement of goods and environmental standards, but global rulemaking regarding intellectual property rights and investor rights. Labor rights are still undecided. Moreover, the rules governing intellectual property rights and investor rights are friendly to the interests of capital.

Third, whether globalization threatens democracy depends on political preferences and the type of globalization. Deep global economic integration along neoliberal lines may destabilize democracy, but deep global integration along social democratic lines may strengthen it. The history of the European Union (EU) offers some evidence supportive of that claim. In the three decades after World War II the EU promoted deep economic integration along social democratic lines and democracy appeared to strengthen. Since then, the EU has shifted to promoting deep economic integration along neoliberal lines and democracy appears to have become more wobbly.

\section{SOME FURTHER COMPLICATIONS: GLOBALIZATION AND POLICY LOCK-IN}

So far, the analysis has focused on how globalization may diminish national policy space. However, there is an additional complication which is that the diminution of policy space can be permanent owing to policy lock-in. In terms of Figure 5 , globalization may be a one-way choice that is irreversible. Having moved away from autarky toward more globalization, it may not be possible to move back in the direction of autarky.

Political scientists (Gill, 1998; Gill and Carter, 2014) emphasize how neoliberal globalization has created a new constitutionalist politics that creates lock-in of international economic governance. That governance lock-in is matched by economic lock-in. The economic theory of policy lock-in (Palley, 2017) draws on the concept of hysteresis, which is a concept drawn from physical chemistry. Systems can change their behavioral characteristics by passing through trigger thresholds 
that act as "switch-on" or "switch-off" mechanisms. In physical chemistry, passing through the switch-on threshold acts as a switch that changes the systems behavior. The new behavioral pattern remains in place until the system passes through the switch-off threshold, at which time the system reverts to its old behavior.

The theory of policy lock-in holds that economic policies, including those associated with globalization, can trigger hysteretic developments in the economic and political system that lock-in policies and lock-out other possibilities. First, policy changes may induce hysteretic changes in the structure of the economy and those changes can make it costly to reverse policy. Second, changes in the economy (even if they are not permanent) may induce hysteretic changes in the political process, thereby permanently changing the political equilibrium and locking-in policy. ${ }^{5}$

Lock-in via globalization is accomplished via multiple mechanisms including network effects, exit costs, and permanently changed political equilibrium. Trade agreements create new rules, which foster new patterns of global production that set the basis for negotiation of future trade and investment agreements. This process of expanding globalization resembles the building of a network (Palley, 2007). For instance, NAFTA established the template for the WTO. Exiting the network is costly for individual countries as they face loss of market access and punitive retaliatory measures. Country go-it-alone reversal of globalization is also discouraged by other large exit costs associated with disrupting existing production and supply chains and reorganizing them along more national lines. ${ }^{6}$

Globalization policy lock-in also results from permanent changes in the political equilibrium. Businesses that have made sunk investment costs in globalization will lobby to retain the system. That includes multinational corporations which have invested offshore, and domestic businesses which rely on imports and have invested in global supply chains. Domestic manufacturers have shut down and their organization capital has been destroyed, raising the cost of reopening. Furthermore, trade unions were concentrated in domestic manufacturing and they have been decimated. That has dramatically changed the political equilibrium and, to the extent the take-off of unions was the product of a unique historical era (the 1930s), it is difficult to rebuild union membership. In sum, globalization contains a powerful structural economic lock-in dynamic that serves to strengthen political forces favoring globalization and weaken the forces against it.

The impact of globalization lock-in is easily illustrated using Figure 5. As globalization deepens, it reduces policy space. The current level of globalization is $G_{0}$. Globalization lock-in means policymakers can further deepen the level of globalization (i.e., increase G) but not reverse it (i.e., decrease G). Viewed in that light, glo-

\footnotetext{
${ }^{5}$ The notion of political equilibrium is discussed by Acemoglu and Robinson (2013).

${ }^{6}$ Brexit and the United Kingdom's exit from the European Union provides another illustration of lockin owing to costs of exit. The UK may still decide to exit for political reasons, but the cost of exit is likely to prove large and that is prompting a backlash and rethink of Brexit.
} 
balization is like a ratchet. Each new step reduces policy space, either by taking policy options entirely off the table or by reducing the effectiveness and scope of existing policy options. A clear example of this impact of globalization is corporate tax policy, where globalization has diminished what is deemed feasible.

Lock-in by globalization has additional anti-democratic implications. By itself, globalization may shrink the extent of policy space. If there is also lock-in, that shrinking becomes irreversible (or at least very costly to reverse). However, the process (or form) of democracy remains intact. Second, the problematic of diminished scope of policy choice also afflicts undemocratic polities so it is not democracy per se that is incompatible. All national political systems may find themselves stressed. Third, the political implications of loss of policy choices depends on the type of globalization. That loss may be of no political consequence if the gains from globalization (i.e., deep economic integration) are politically popular. Here, the history of the EU is relevant again. Deep European economic integration was popular when it was generating widely shared economic gains.

\section{GLOBALIZATION AND CURRENT POLITICAL DEVELOPMENTS: ANTI-DEMOCRATIC BACKLASH AND POLITICAL BRITTLENESS}

The above arguments help understand current political developments which are marked by anti-democratic backlash and political brittleness.

a) Globalization and democracy: anti-democratic backlash and elite responsibility

In many countries there now appears to be a nationalist anti-democratic backlash that takes the form of gravitation toward right-wing political parties with authoritarian inclinations. ${ }^{7}$ That backlash is partly attributed to globalization, particularly trade-induced manufacturing job loss and increased immigration. The popular demand is for reassertion of national sovereignty.

The backlash raises several important issues. First, it tacitly questions economists' claims regarding the economic gains from deep international integration. Second, it spotlights the political costs of globalization which are not factored into economists' globalization benefit - cost analysis.

Unfortunately, it is easy to characterize the backlash as just the intolerance of "deplorables", when there is actually good political reason for the backlash. The current incarnation of globalization reflects two features. First, it is an elite project, supported by both sides of the political establishment. Second, the project has been designed according to the ideology and principles of neoliberal economics. That

\footnotetext{
${ }^{7}$ In the US it is evidenced by the 2016 election of President Donald Trump and the embrace of his politics by the Republican Party. In Western Europe it is evidenced by the Brexit controversy and the rise of right-wing political parties in national legislatures.
} 
political configuration has blocked alternative policies and has also blocked relief from the economic injuries inflicted by neoliberal globalization. In turn, that has fostered the anti-democratic anti-establishment backlash.

Better if the backlash had taken the form of push for an alternative globalization, but that is not how politics often works in stressed times. ${ }^{8}$ Instead, the combination of economic distress, lack of establishment leadership, and a dominant economic ideology that suppresses awareness of alternatives, has facilitated a nationalist anti-democratic backlash. Viewed in that light, the deep responsibility for the backlash lies with establishment elites who designed and implemented neoliberal globalization and combined to block alternatives.

That brings us back to political critique of the trilemma which unwittingly obscures that responsibility. The reason is the trilemma's incomplete representation of available policy choices, particularly regarding the possibility of alternative nation state sponsored globalization as discussed in the fifth section above. The incomplete representation obscures the fact that globalization has been an explicit political choice defined by "degree" of globalization, "type" of globalization, and “dimensions' of globalization.

\section{b) Globalization and democracy: lock-in and political brittleness}

A second feature of the current political environment is a tendency to political brittleness, defined as abrupt changes of policy direction and arrangements. Such brittleness is exemplified by the Brexit saga. Lock-in offers an explanation of why political change may be abrupt and marked by crisis.

Lock-in implies it is costly to exit existing economic and political arrangements. Consequently, polities may remain attached to dysfunctional governance and policy regimes until the costs of not addressing existing problems are perceived to exceed the costs of exiting the system. When the burdens of the existing policy regime system are small, it is not worth paying the large costs of exit. However, once those burdens become large, the calculus may suddenly reverse and the regime may collapse abruptly. Lock-in therefore provides an explanation of why political and economic breaks often tend to be big, costly, and discrete when they happen.

That dynamic appears to characterize recent "populist" political developments which challenge the neoliberal policy paradigm and globalization. Electorates may be reaching the point where the costs of policy exit are perceived to be less than the costs of sticking with the current policy regime.

From a political perspective, globalization lock-in compounds the challenge of diminished national policy space and may increase the likelihood of an anti-democratic turn. If electorates feel they are permanently unable to address economic inequities generated by globalization, that may generate political frustrations which

\footnotetext{
${ }^{8}$ In fact, there has been a significant amount of push for an alternative globalization but, for complex reasons beyond the scope of the current discussion, it has not gained the same political traction as the nationalist right-wing backlash.
} 
express themselves in an anti-democratic turn. In sum, lock-in can help explain both political brittleness and anti-democratic political turns. However, such outcomes are only a possibility and not an inevitability. ${ }^{9}$

\section{CONCLUSION}

The political economy of globalization is often framed in terms of Rodrik's (2011) globalization political trilemma. This paper has proposed a reframing that rests on national policy space. Globalization causes changes in national policy space that have drop-down implications for national sovereignty and democratic politics.

In analyzing the impact on sovereignty there is need to distinguish between "formal" and "effective" sovereignty. With regard to democratic politics, there is need to distinguish between "process" and "content".

Globalization involves choices regarding the "degree" of international economic integration, the "type" of international economic integration, and the "dimension" of international economic integration. That makes it a fundamentally political project.

The multi-faceted nature of the choices means there are no inevitable implications for sovereignty and democracy. To the extent that globalization is now driving a nationalistic anti-democratic turn in politics, the responsibility lies with political elites. Globalization has been a bi-partisan elite project, designed according to neoliberal principles. That configuration has inflicted economic injury while blocking alternative policies, in turn fostering an anti-democratic anti-establishment backlash.

\section{REFERENCES}

Acemoglu, D. and J.A. Robinson (2013), “Economics versus politics: pitfalls of policy advice”, Journal of Economic Perspectives, 27 (2), 173 - 192.

Gill, S. (1998), “New Constitutionalism, Democratization and Global Political Economy”, Pacifica Review: Peace, Security and Global Change, 10(1), 23-38.

Gill, S. and Cutler, C. (2014), New Constitutionalism and World Order, Cambridge, UK: Cambridge University Press.

Keynes, J.M. (1933), “National self-sufficiency”, The Yale Review, 22 (4), June, 755 - 769.

Krugman, P. (1999), “O Canada - a neglected nation gets its Nobel”, Slate Magazine, 10 October.

Obstfeld, M. and Taylor, A.M. (1997), "The great depression as a watershed: international capital mobility over the long run”, NBER Working Paper N. 5960, NBER, Cambridge: MA.

Palley, T.I. (2007), "Locked in and Locked out”, The Guardian, Thursday 10 May. Reprinted in Palley. T, The Economic Crisis: Notes from the Underground. CreateSpace 2012: 86 - 87.

\footnotetext{
${ }^{9}$ Greece is instructive in this regard. Greece has found itself locked into the euro, but democratic politics have persisted. The important point is that lock-in implies nothing inevitable for democracy.
} 
Palley, T.I. (2012), From Financial Crisis to Stagnation: The Destruction of Shared Prosperity and the Role of Economics, Cambridge University Press.

Palley, T.I. (2015), "Escaping stagnation and restoring shared prosperity: a macroeconomic policy framework for job-rich growth”, Employment Working Paper No. 170, Employment Policy Department, ILO, Geneva, Switzerland.

Palley, T.I. (2016), "Betrayed again, this time by unconvincing arguments for the TPP", Common Dreams, July 5.

Palley, T.I. (2017), "A theory of economic policy lock-in and lock-out via hysteresis: rethinking economists' approach to economic policy”, Economics: The Open-Access, Open-Assessment E-Journal, 11, 1-8.

Rodrik, D. (2011), The Globalization Paradox: Democracy and the Future of the World Economy, New York: W.W. Norton \& Company.

Ruggerio, R. (1996), Remarks at the United Nations Conference on Trade and Development, October 8.

Stein, A. A. (2016), “The Great Trilemma: Are globalization, democracy, and sovereignty compatible?” International Theory, 8 (2), 297 - 340.

Verovšek, P. (2020), "Brexit and the Misunderstanding of Sovereignty”, Social Europe, December 9. 